\title{
Use of a type IIB external skeletal fixator in experimental tarsocrural arthrodesis in dogs
}

\author{
Artrodeses tarsocrurais experimentais em cães utilizando fixadores esqueléticos \\ externos do tipo IIB
}
DÓREA NETO, Francisco de Assis ${ }^{1 *}$; ORIÁ, Arianne Pontes ${ }^{2}$; PADILHA FILHO, João Guilherme $^{3}$; REGONATO, Everton ; MORENO, Juan Carlos Duque ; CANOLA, Júlio Carlos ${ }^{3}$

\author{
${ }^{1}$ União Metropolitana para o Desenvolvimento da Educação e Cultura, Faculdade Agrária e de Saúde, Lauro \\ de Freitas, Bahia, Brasil. \\ ${ }^{2}$ Universidade Federal da Bahia, Escola de Medicina Veterinária e Zootecnia, Departamento de Patologia \\ e Clínicas Veterinárias, Salvador, Bahia, Brasil. \\ ${ }^{3}$ Universidade Estadual Paulista, Faculdade de Ciências Agrárias e Veterinárias, Departamento de Clínica \\ e Cirurgia Veterinária, Jaboticabal, São Paulo, Brasil. \\ ${ }^{4}$ Centro Universitário de Rio Preto, Rio Preto, São Paulo, Brasil. \\ ${ }^{5}$ Universidade Federal de Goiás, Escola de Veterinária, Goiania, Goiás, Brasil. \\ *Endereço para correspondência: d.oria@terra.com.br
}

\section{SUMMARY}

The aim of the present study was to evaluate the usefulness of type IIb external skeletal fixators with a transarticular pin in experimental tarsocrural arthrodesis. Twelve adult mongrel dogs of both sexes, ranging in age from two to five years and weighing 12 to $25 \mathrm{~kg}$, were used. The configuration of the fixator consisted in the application of a transarticular Steinmann pin and of centrally threaded pins to the proximal portion of the tibia and calcaneus and to the distal portion of the metatarsal bones. In addition, Schanz pins were inserted into the medial and lateral side of the tibia and into the medial side of the metatarsal bones. Radiographs were taken 15; 30 and 45 days after surgery. Bone fusion of the treated joints were observed at 30 days in all animals, and the implants were removed after 45 days. Loosening of the centrally threaded pins was observed in all groups, especially for those applied to the calcaneus. The configuration of the external fixator proposed here was found to be satisfactory in terms of bone union for all joints during the same period, irrespective of the weight of the animal.

Keywords: dog, experimental surgery, joint fusion, small animals, veterinary orthopedics

\section{RESUMO}

O objetivo com este trabalho foi avaliar a utilização de fixadores esqueléticos externos do tipo Ilb com pino transarticular em artrodeses tarsocrurais experimentais. Foram empregados 12 animais da espécie canina, machos e fêmeas, sem raça definida, adultos, com idades entre dois e cinco anos, peso entre 12 e $25 \mathrm{~kg}$. A configuração do fixador foi estabelecida com a aplicação de pino de Steinmann transarticular, pinos com rosca central na porção proximal da tíbia, calcâneo e distal nos metatarsianos, pinos de Schanz, também, foram aplicados na face medial e lateral da tíbia e na face medial dos metatarsianos. Os intervalos de tempo para as análises radiográficas foram 15; 30 e 45 dias do pós-cirúrgico. Foram observadas fusão das articulações que sofreram artrodese aos 30 dias em todos os animais, sendo, os implantes removidos aos 45 dias. Houve afrouxamento dos pinos de rosca central em todos os grupos, sobretudo os pinos aplicados no calcâneo. A configuração do fixador externo proposto por este trabalho, mostrou-se satisfatória para a união óssea de todas as articulações em um mesmo período, independentemente do peso do animal.

Palavra chave: cão, cirurgia experimental, fusão articular, pequenos animais, ortopedia veterinária 
Rev. Bras. Saúde Prod. Anim., Salvador, v.13, n.2, p.541-549 abr./jun., 2012 http://www.rbspa.ufba.br ISSN 15199940

\section{INTRODUCTION}

Trauma to the paw of dogs and cats may result in soft tissue and bone lesions. These lesions frequently result in instability due to rupture of the carpal or tarsal ligaments (MUIR \& NORRIS, 1999). Instability induces pain due to abnormal movement and the tension placed on the soft tissues and nerves of the joint. Thus, arthrodesis relieves pain by providing a rigid support

Arthrodesis is a relevant limb-sparing procedure and represents an alternative to amputation. This method is routinely indicated for painful disorders and instability and loss of articular function. Bone fixation should be rigid, with compression of the contact surfaces, and long lasting (MOAK et al., 2000; BENSON \& BOUDRIEAU, 2002; HARASEN, 2002; RAHAL et al., 2007; THÉORET \& MOENS, 2007).

Different bone fixation devices have been reported in the literature as a method for stabilization in arthrodesis, such as bone plates (MUIR \& NORRIS, 1999; LI et al., 2000; MCKEE et al. 2004; GUERRERO \& MONTAVON, 2005), screws in combination with tension band wiring (PIEMARTEI \& FLO, 1997) external skeletal fixators (ESFs) (GRUMADAS, 1988; BENSON \& BOUDRIEAU, 2002; DÓREA NETO et al., 2004; DÓREA NETO et al, 2007), or circular fixators (COLLINS et al., 2000; RAHAL et al. 2007).

Particularly in the case of tarsal arthrodeses, ESFs are applied to open or shearing injuries of the hock and to open luxation with comminuted fractures of the tibial trochlea or condyles of the talus (PIEMARTEI \& FLO, 1997; BENSON $\&$ BOUDRIEAU, 2002). The objective of the present study was to evaluate the clinical and radiographic outcomes in dogs managed by surgical experimental tarsocrural arthrodesis stabilization using a type IIb ESF with a transarticular pin.

\section{MATERIAL AND METHODS}

For the present study, twelve adult mongrel dogs of both sexes, ranging in age from two to five years and weighing 12 to $25 \mathrm{~kg}$, were used. The research protocols were approved by the Ethics and Animal Well-Being Committee of the Faculty of Agricultural and Veterinary Sciences, UNESP, Jaboticabal Campus, protocol number 26093.

The dogs received levomepromazine hydrochloride (Neozine $\AA)$ ( $1 \mathrm{mg} / \mathrm{kg}, \mathrm{IV})$ and vedaprofen (Quadrisol 5尺) $(5 \mathrm{mg} / \mathrm{kg}, \mathrm{PO})$. Anesthesia for orotracheal intubation was induced by the intravenous administration of propofol ${ }^{\circledR} \quad(5$ to $8 \mathrm{mg} / \mathrm{kg}$ ), and was maintained by a combination with an inhalatory anesthetic (Halothane $\AA$ ) ) in a semi-closed system. Analgesia consisted of the epidural infusion of morphine (Dimorf $\AA$ ) $(0.1 \mathrm{mg} / \mathrm{kg})$ and ketamine (Ketanime $\mathrm{S} \circledast$ ) $(0.3 \mathrm{mg} / \mathrm{kg})$ in a final volume of $0.3 \mathrm{ml} / \mathrm{kg}$ adjusted with $0.9 \% \mathrm{NaCl}$.

The dogs were positioned in dorsal decubitus for the surgical procedures. The tarsocrural joints were approached medially (PIERMATTEI, 1997), and an osteotomy was performed in the medial malleolus using an osteotome and a Luer rongeur for exposure of the articular surface. The cartilage was removed with curettes and an electrical burr coupled to high-rotation instruments (Dremel ${ }^{\circledR}$ ), preserving the bone contour of the joint. After preparation of the joints, a bone graft collected from the tibial crest was placed in the articular space. The joints were positioned at an angle ranging from 135 to $145^{\circ}$. A small incision was then made on the caudal side of the calcaneus through which a $3 \mathrm{~mm}$ 
Steinmann pin was inserted from the calcaneus and talus in the direction of the medullary canal of the tibia. The subcutaneous tissue and the skin were sutured routinely.

Due to variation in the weight of the animals, the ESF was applied using the same fixator configuration for all animals, varying only in the thickness of the pins (Table 1). For the aplication of the pins drills were used with profile of $0,5 \mathrm{~mm}$ inferior to the pin and used cordless drive drill (Makita®) with low rotation being irrigated with physiologic solution during the perforation. The fixator was prepared by inserting centrally threaded positive profile pins percutaneously in the middle third of the tibia on the medial side, a second pin in the distal portion of the metatarsal bones on the medial side, and a third one in the calcaneus also on the medial side. The centrally threaded pins were coupled to $6.5 \mathrm{~mm}$ parallel aluminum connecting arch-shaped bars.

Table 1. Thickness of the centrally threaded and Schanz pins used in the tibia, calcaneus and metatarsus of dogs submitted to tarsocrural arthrodesis using a type IIb external skeletal fixator according to the body weight of the animals

\begin{tabular}{lccc}
\hline Weight $(\mathrm{kg})$ & Centrally threaded pins $(\mathrm{mm})$ & Schanz pins $(\mathrm{mm})$ & Bone \\
\hline \multirow{3}{*}{$12-15$} & 3.0 & 2.0 & Tibia \\
& 2.5 & - & Calcaneus \\
& 2.0 & 2.0 & Metatarsus \\
\hline \multirow{3}{*}{$16-20$} & 3.0 & 2.5 & Tibia \\
& 2.5 & - & Calcaneus \\
& 2.5 & 2.5 & Metatarsus \\
\multirow{3}{*}{$21-25$} & 4.0 & 3.0 & Tibia \\
& 3.0 & - & Calcaneus \\
& 2.5 & 2.5 & Metatarsus \\
\hline
\end{tabular}

Aluminum clamps and stainless steel screws were used to fix the pins to the connecting bars. The connecting bars were positioned in such a way as to facilitate radiographic assessment. To confer greater stability and resistance, Schanz pins were inserted percutaneously on the medial and lateral side of the tibia using the clamps as perforation guides. Similar pins were inserted into the metatarsal bones on the medial side which, in turn, were fixed to the connecting bars through the previously positioned clamps. Finally, two other $3 \mathrm{~mm}$ stainless steel bars were placed in the main connecting bars to render the configuration more resistant to force as shown in Figure 1.
During the postoperative period, padded bandages and an Elizabethan collar were used throughout the maintenance of the fixator. Vedaprofen (Quadrisol $5 \circledR)(5 \mathrm{mg} / \mathrm{kg}, \mathrm{PO}, \mathrm{SID})$ and cephalexin $(\mathrm{EMS} \AA$, Generic drug) $(25 \mathrm{mg} / \mathrm{kg}$, PO, BID) were administered for 10 days. The implants were removed after radiographic assessment at 45 days under levomepromazine hydrochloride $(1 \mathrm{mg} / \mathrm{kg}, \mathrm{IV})$ and tiletamine-zolazepam (Zoletil®) $(10 \mathrm{mg} / \mathrm{kg}, \quad \mathrm{IV})$ anesthesia. After removal of the implants, padded bandages were applied for an additional 15 days to offer greater comfort to the animals. 

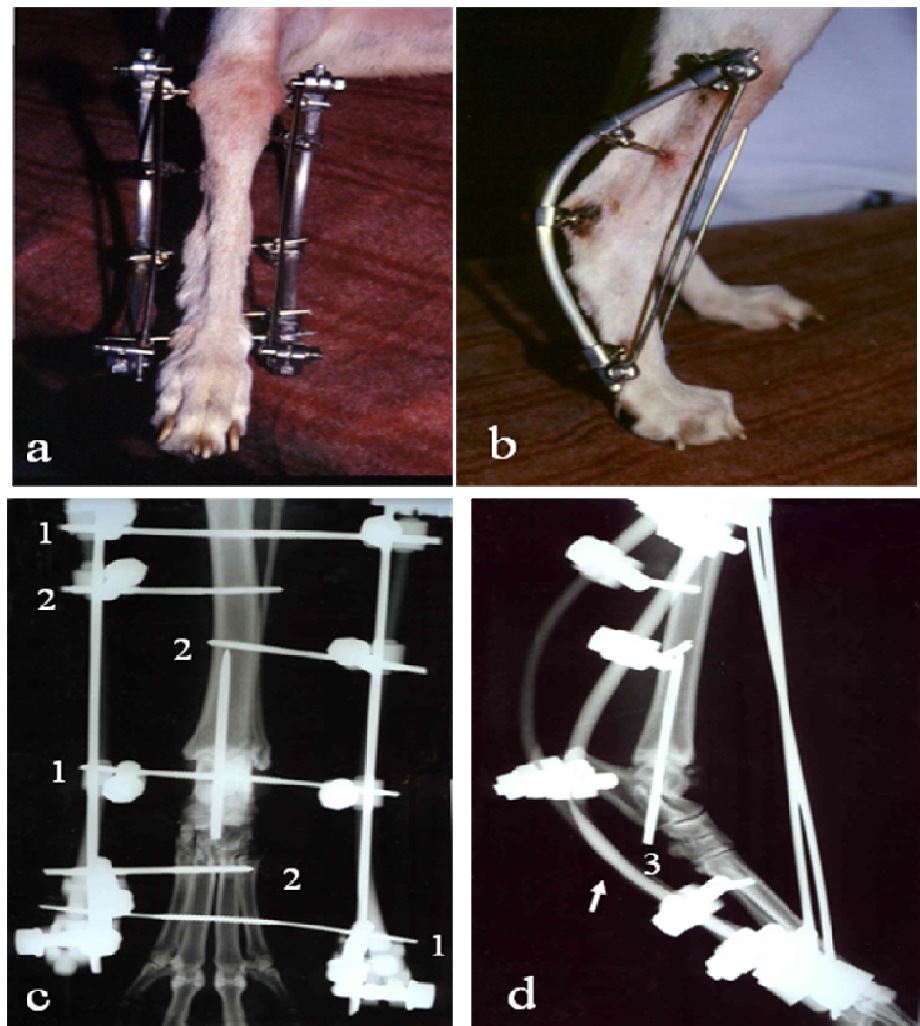

Figure 1. Photographic and radiographic images of the tarsocrural arthrodesis in a dog using a type IIb external skeletal fixator. a) Photographic image in the anterodorsal view. Note the centrally threaded pins inserted into the tibia, metatarsal bones and calcaneus, and Schanz pins inserted into the medial and lateral side of the tibia and into the medial side of the metatarsi. b) Photographic image: lateral view of the fixator showing the arch-shaped aluminum connecting bars and the stainlesssteel connecting bar. c) Radiographic image in the dorsoplantar projection. Note the arrangement of the bone fixation pins: (1) centrally threaded positive profile pins inserted into the tibia, metatarsal bones and calcaneus; (2) Schanz pins on the medial and lateral side of the tibia and on the medial side of the metatarsi; (3) Steinman pin applied through the tibiotarsal joint. d) Radiographic image in the lateromedial projection. Observe the arrangement of the lateral connecting bars in the shape of an arch (arrow)

The animals were examined daily regarding the presence of an inflammatory reaction and graft rejection by inspection and palpation. The ESFs were inspected daily for the first week and then every 3 days until their removal. Lameness was classified into four categories: no lameness - grade 3, lameness with continuous weightbearing on the limb - grade 2, lameness with intermittent weightbearing on the limb - grade 1, and non-weightbearing grade 0 .

The joints submitted to arthrodesis were examined radiographically in the dorsoplantar and mediolateral projections. For the dorsoplantar projection, a support was used to elevate the limb and thus to permit better visualization of the joint. Radiographic examination was performed 
before surgery, immediately after the procedure, and 15; 30 and 45 days after surgery.

\section{RESULTS}

The dogs were in good clinical health throughout the study period, with no systemic or local alterations being observed that might indicate lack of success of the surgical procedure. Skin wound healing was observed 6 to 10 days after placement of the arthrodesis. The animals showed intense edema and hematomas in the operated limb during the first day after surgery. Improvement was observed on the third day, with edema changing from moderate to discrete on the fifth day and completely regressing on the eighth day.

With respect to the degree of lameness, the animals were non-weightbearing on the operated limb (grade 0) on the first day, presented intermittent weightbearing lameness (grade 1) on average up to postoperative day 5 , and continuous weightbearing (grade 2) until removal of the fixators. The absence of lameness (grade 3) was only obtained 30 days after removal of the internal metal implant (transarticularly applied pin).

Examination of the fixators revealed a sanguinolent exudate on the lateral side of the centrally threaded pins on the tibia. Two dogs presented a serosanguinolent exudate by day 35 , and bleeding at the same site was observed in two other dogs. Edema in the region of the calcaneus was observed in three dogs by day 40 . Two dogs showed a serosanguinolent exudate around the centrally threaded pin of the metatarsal bones on the medial side.

All joints were radiographically normal before surgery. After the surgical procedure, no signs of bone infection were observed in any of the animals, either in the joints receiving the arthrodesis or at the pin insertion sites at any time of assessment. Radiographic examination revealed signs of edema immediately after surgery. Bone union of the treated articular surfaces was visible after 30 days as shown in Figure 2.

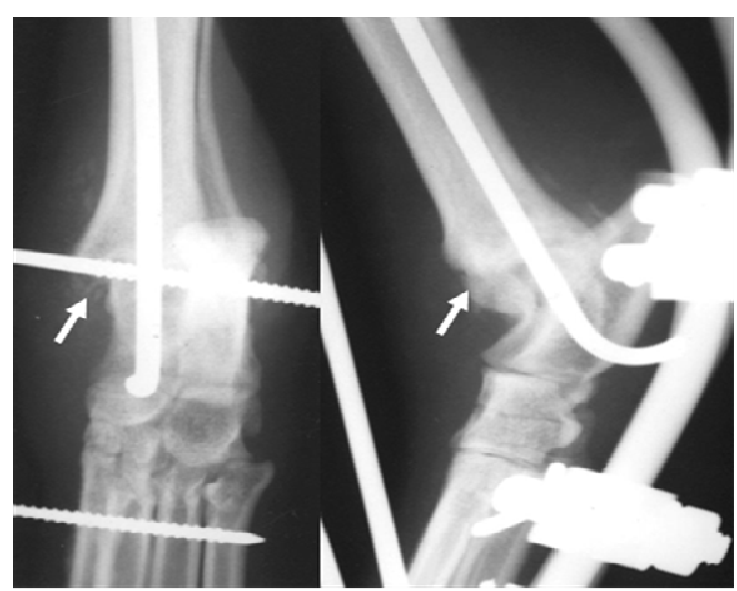

Figure 2. Radiographic images in the dorsoplantar (a) and lateral (b) projections of the tarsocrural arthrodesis in a dog using a type II external skeletal fixator 30 days after the surgical procedure. Note the bone union of the articular surfaces of the tibial cochlea and talar trochlea without gap formation (arrows) 
Radiographic analysis of the fixators showed loosening of the fixation pins in all groups by day 15 . Initial loosening was observed for the centrally threaded pins, especially those inserted into the calcaneus. Heavier animals weighing 21 to $25 \mathrm{~kg}$ presented higher loosening rates than lighter animals weighing 12 to $20 \mathrm{~kg}$. A lower pin loosening rate was observed for animals with a longer tibia, where the centrally threaded pins were inserted more distant from the tarsocrural joint.

\section{DISCUSSION}

The type IIb ESF device was well tolerated by the animals and permitted rapid bone union of the arthrodesis after 30 days and consequent removal of the implant at 45 days. The time of bone union of the arthrodesis was relatively shorter than that reported by Johnson \& Belenger (1980) who used a bone fixation plate as stabilization method, and by Grumadas (1988) who used ESFs in carpal arthrodesis and observed bone fusion after 60 days. Dórea Neto et al. (2004), who performed carpal arthrodesis in two cats using an ESF and hydroxyapatite as a bone graft substitute, observed stable bone union after 30 and 60 days, respectively.

Dórea Neto et al. (2007) used a ESFs in arthrodesis in clinical cases, employing hydroxyapatite as a graft, and observed rapid bone healing which occurred, on average, after 60 days. Among the cases evaluated in that study, 10 arthrodeses were performed in the tarsus, carpus, and elbow using type I, type II and type IIb ESFs, with good to excellent results and the return to limb function being obtained in all cases. In the comparison of these arthodesis in the different articulations using ESFs it was not observed any difference in bone healing process.

In the present study, the rapid bone union observed with the ESFs might have been due to less damage to the soft tissues during application of this bone stabilization method. In addition, several authors emphasize that the biomechanical characteristics of the ESFs also permitted the maintenance of axial elasticity during the bone healing process (BENSON \& BOUDRIEAU; 2002; RAHAL, 2004). Another factor that might have influenced the bone union was the bone marrow that overflow during the application of the transarticular pins on the bone graft.

Evaluating seven dogs with several carpal and tarsal shearing injuries treated with an immediate arthrodesis, Benson \& Boudrieau (2002) reported that the ESFs behaved as a stable fixation method, not requiring the application of implants at the site of the contaminated wound and permitting bone fusion within 12 weeks and closure of the soft tissue damaged by abrasion.

ESFs are very versatile and the final design can be simple or highly complex depending on the requirements for stabilization and also on the anatomic arrangement of the limb. According to Piermattei \& Flo (1997), type IIb ESFs might be used in large breeds since it confers greater rigidity on the construct, neutralizing the bending load at the arthrodesis point.

Bone fusion was evaluated by physical and radiographic examination at predetermined times as established by Piermattei \& Flo (1997). On average, the acute inflammatory response and edema were reduced by the $5^{\text {th }}$ postoperative day, being subsequently replaced with solid volume resulting from the healing of the soft tissues and periosteum. 
In the present experiment, a modified configuration was used in which the shape of an arch was preserved in animals weighing 12 to $25 \mathrm{~kg}$ and only the thickness of the pins was altered. However, the number of pins applied to dogs weighing more than $16 \mathrm{~kg}$ was insufficient, resulting in early pin loosening, especially of the centrally threaded pins.

With respect to the centrally threaded pins inserted into the calcaneus, the initial objective was to confer a greater stability on the configuration and to permit visualization of the joint. However, based on the results obtained, we believe that a biomechanical assay would be indicated to better understand the events and to identify alternatives for future studies.

Diamond et al. (1999) evaluated seven arthrodeses using a type I ESF configuration for stabilization of the open tarsal lesions. Reported complications included premature loosening of the fixation pins accompanied by superficial infection, fracture of the connecting bars, and removal of the device by the animal during a walk. The authors stated that the complications observed in the ESF group could be avoided if more resistant ESFs were used, i.e., a type II instead of a type I ESF or by the addition of another connecting bar joining the proximal to the distal pin and thus creating a triangular configuration.

No radiographic signs of bone infection were observed in the joints receiving the arthrodesis or at the pin insertion sites at any time of assessment. It is likely that the secretion observed over the fixation pins was caused by soft tissue movement in the implants, as well as movement of the loose pins in the bone. Since there were no radiographic signs indicative of bone infection, no cultures or antibiograms were obtained from the secretions derived from these pins.
Thus, only local cleaning with an antiseptic and protection of the pin with antiseptic-soaked gauze were performed. The loosening of the centrally threaded pins applied to the tibia, calcaneus and metatarsal bones observed in some animals might be attributed to complications such as excessive load on these bones, especially the calcaneus, which favors the occurrence of microfractures around the pin-to-bone interface. This overload might also be explained by the fact that all mechanical structures of the joints are projected to promote articular movement, and therefore act by working against the immobilization of the arthrodesis at the fixation points (DÓREA NETO et al. 2007).

Thermal necrosis during the aplication of the pins might have influenced the loosening, however, the largest area of absorption bone was observed in centrally threaded pins applied in the calcaneus, metatarsal bones and tibia proximal. This fact can be related to the own sustentation characteristic and distribution of the load on this pins differently of the Schanz pins.

In addition, loosening of the calcaneal pins can be attributed to the dynamics of the fixator itself and also to the bone structure of the calcaneus, i.e., small amounts of sponge bone for fixation of the threaded pin. One alternative for the placement of the calcaneal pin is the fixation of a transarticular pin to the fixator, which would increase the stability of the configuration and facilitate its removal after bone fusion.

The present results permitted to conclude that type Ilb ESFs are suitable alternative implants for tarsocrural arthrodesis in dogs. The loosening observed for the pins applied to the calcaneus are due to excessive load on the fixator. Incorporation of a transarticular pin in the fixator and, removal centrally threaded 
Rev. Bras. Saúde Prod. Anim., Salvador, v.13, n.2, p.541-549 abr./jun., 2012 http://www.rbspa.ufba.br ISSN 15199940

pins of the calcaneus might improve its dynamics and reduce overload.

\section{ACKNOWLEDGEMENTS}

The authors would like to thank FAPESP (Fundação de Amparo a Pesquisa do Estado de São Paulo) for the financial support (grants 00/12655-1 and 00/007715-5).

\section{REFERENCES}

BENSON, J.A.; BOUDRIEAU, R.J. Several carpal and tarsal shearing injuries treated with an immediate arthrodesis in seven dogs. Journal of the American Animal Hospital Association, v.38, n.4, p.370-380, 2002.

DIAMOND, D.W.; BESSO, J.; BOUDRIEAU, R.J. Evaluation of joint stabilization for treatment of shering injuries of the tarsus in 20 dogs. Journal of the American Animal Hospital Association, v.35, n.2, p.147-153, 1999.

COLLINS, K.E.; LEWIS, D.D.; LANZ, O.I.; NEWELL, S.M. Use of a circular external skeletal fixator for stifle arthrodesis in a dog. Journal Small Animal Practice, v.41, n.7, p.312-315, 2000.

DOREA NETO, F.A.; ORIÁ, A.P.; PADILHA FILHO, J.G.; FURLANI, J.M.; SANTOS, L.A. Artrodese do carpo em gatos associada a hidroxiapatita. Ciência Rural, v.34, n.3, p.931-934, 2004.
DOREA NETO, F.A.; PADILHA

FILHO, J.G.; SANTOS, L.A.; ORIÁ, A.P.; CANOL, J.C.; STEFANE, S.A.; REGONATO, E. The use of hydroxiapatite for arthrodesis in dogs and cats: a clinical study, Arquivos Brasilieros de Medicina Veterinaria e Zootecnia, v.59, n.4. p.932-938, 2007.

GUERRERO, T.G.; MONTAVON P.M. Medial plating for carpal panorthrodesis. Veterinary Surgery, v.34, n.2, p.153-158, 2005.

GRUMADAS, C.E.S. Correção de instabilidade articular experimental do carpo do cão através de pan-atrodese obtida com aparelho de fixação externa com barras de acrílico. Revista centro de ciências Rurais, v.18, n.1, p.47-58, 1988.

HARASEN, G. Arthrodesis - part II: tarsus. Canadian Veterinary Journal, v.43, n.10, p.806-808, 2002.

JOHNSON, K.A.; BELLENGER, C.R. The effects of autologous bone grafting on bone healing after carpal arthrodesis in the dog. The

Veterinary Record, v.107, n.9, p.126$132,1980$.

LI, A.; GIBSON, N.; CARMICHAEL, S.; BENNETT, D. Thirteen pancarpal arthrodesis using 2.7/3.5 mm hybrid dynamic compression plates.

Veterinary and Comparative Orthopaedics and Traumatology, v.12, n.3, p.102-107, 2000.

MCKEE, W.M.; MAY, C.; MACIAS, C.; LAPISH, J.P. Pantarsal arthrodesis with a customized medial or lateral bone plate in 13 dogs. The Veterinary Record, v.154, n.6, p.165170, 2004. 
Rev. Bras. Saúde Prod. Anim., Salvador, v.13, n.2, p.541-549 abr./jun., 2012 http://www.rbspa.ufba.br ISSN 15199940

MOAK, P.C.; LEWIS, D.D.; ROE, S.C.; HAAN, J.J. Arthrodesis of the elbow in three cats. Veterinary and Comparative Orthopaedics and Traumatology, v.13, n.3, p.149-153, 2000 .

MUIR, P.; NORRIS, J.L.

Tarsometatarsal subluxation in dogs partial arthrodesis by plate fixation.

Journal of the American Animal Hospital Association, v.35, p.155-162, 1999.

PIERMATTEI, D.L.; FLO, G.L. Arthrology In: Handbook of small animal orthopedics and fracture repair. 3rd ed. Philadelphia: Saunders, 1997. p.170-200.
RAHAL, S.C.; VOLPI, R.S.; HETTE, K. TEIXEIRA NETO, F.J.; VULVANO, L.C. Arthrodesis tarsocrural ou tarsometatarsal in 2 dogs using circular external skeletal fixator. Canadian Veterinary Journal, v.47, n.9, p.894-898, 2006.

THÉORET, M.C.; MOENS, N.M.M. The use of veterinary cuttable plates for carpal and tarsal arthrodesis in small dogs and cats. Canadian Veterinary Journal, v.48, n.2, p.165-168, 2007.

Data de recebimento: 26/01/2012

Data de aprovação: 13/02/2012 